\title{
Effect of Supplementing Bypass Fat on Milk Yield, Milk Composition and Chemical Parameters of Ghee in Crossbred Cows
}

\author{
N. Veena ${ }^{1 *}$, M. Wadhwa ${ }^{2}$, H. Mehta ${ }^{1}$, A.K. Barui ${ }^{1}$, A.K. Puniya ${ }^{1}$, \\ J.S. Hundal ${ }^{2}$ and R.S. Grewal ${ }^{2}$
}

${ }^{1}$ Department of Dairy Chemistry, College of Dairy Science and Technology, ${ }^{2}$ Department of Animal Nutrition, College of Veterinary Science, Guru Angad Dev Veterinary and Animal Sciences University, Ludhiana, 141004, Punjab, India

*Corresponding author

A B S T R A C T

\section{Keywords}

Bypass fat, Crossbred cows, Milk yield, Milk composition, Chemical parameters of ghee

Article Info

Accepted:

18 September 2018

Available Online:

10 October 2018
Five lactating crossbred cows were selected to investigate the effect of bypass fat supplementation on milk yield, milk composition and chemical parameters of ghee. There were no significant differences in milk yield, milk composition yield and fat proteincorrected milk yield, compared to base levels, recorded at the time of starting experimental feeding. The bypass fat supplementation increased $(\mathrm{P}>0.05)$ the fat content but significantly decreased the protein and SNF content in milk. Ghee prepared by direct cream method was evaluated for its Reichert Miessl (RM), Polenske value (PV), Butyro refractometer (BR) reading and Refractive index (RI). On feeding bypass fat supplement, $\mathrm{RM}$ value in ghee increased from 26.65 to 28.31 but PV decreased from 1.17 to 0.83 . However, no significant difference in BR reading and RI on bypass fat supplementation.

\section{Introduction}

Many studies have been conducted on feed supplementation with particular feeds either to enhance milk production or modify the fatty acid profile, especially to increase the fraction of unsaturated fatty acids in milk fat. High energy supplements such as fat and oils are added to increase energy density of animal diets, while protein sources of better amino acid composition for milk synthesis are being used in dairy animals diets (Tripathi, 2014). In general, supplements of plant oils or oil seeds rich in unsaturated fatty acids $\left(\mathrm{C}_{18: 2}\right.$ and $\left.\mathrm{C}_{18: 3}\right)$ reduce the proportion of short- and medium chain fatty acids $\left(\mathrm{C}_{6: 0}-\mathrm{C}_{16: 0}\right)$ and increase the proportion of $\mathrm{C}_{18: 0}$. Calcium salts of longchain fatty acids has been shown to be effective as ruminally inert fat supplements for lactating cows and are often fed to enhance energy density of ration and energy intake in early lactation without compromising the activity of rumen microflora (Tyagi et al., 2009).

The ghee (clarified butterfat) is one of the important sources of fat in the Indian diet. RM value, polenske value (PV) and $\mathrm{BR}$ reading 
are considered as important quality parameters of ghee under legal standards (Food Safety Standard Authority of India). RM value is substantially a measure of the lower chain volatile water soluble fatty acids i.e butyric acid $\left(\mathrm{C}_{4: 0}\right)$ contributes about $3 / 4^{\text {th }}$ and caproic acid $\left(\mathrm{C}_{6: 0}\right)$ about $1 / 4^{\text {th }}$ to this value whereas $\mathrm{PV}$ is a measure of lower chain volatile water insoluble fatty acids i.e. caprylic acid $\left(\mathrm{C}_{8: 0}\right)$ contributes about $1 / 4^{\text {th }}$ and capric acid $\left(\mathrm{C}_{10: 0}\right)$ about $3 / 4^{\text {th }}$ to this value. Butyro-Refractometer (BR) reading or refractive index which measures the index of refraction between air and the liquid fat, and vary with the nature of the fat, is usually determined at $40^{\circ} \mathrm{C}$. Many previous research literatures showed the effect of different feeds for dairy cows upon physical and chemical parameters of milk fat produced. For instance, Cranfield (1911) worked with coconut cake and linseed cake and Cranfield and Taylor (1915) with linseed cake and hempseed cake. They showed that when cows were removed from poor pasture to wellbalanced rations containing these products a considerable rise in the RM, Kirschner, and Polenske numbers and a fall in the index of refraction occurred. Smith et al., (1916) reported the feeding of cottonseed oil lowered the saponification number and the soluble fatty acids and increased the insoluble fatty acids. In the present study, a feeding trial was conducted to investigate the effect of bypass fat supplementation on milk yield, milk composition and chemical parameters of ghee in crossbred cows.

\section{Materials and Methods}

\section{Experimental design and diets}

This study was conducted during March to May months at Livestock Research Farm of Guru Angad Dev Veterinary and Animal Sciences University (GADVASU), Ludhiana, Punjab. A farm-level feeding trial was undertaken to evaluate the effect of supplementing bypass fat on milk yield, composition and chemical properties of ghee in early lactating cross bred cows. A feeding trial was conducted on five lactating crossbred cows, yielding 7-8 kg milk per animal per day for 7 weeks. Animals were selected based on milk yield, fat per cent and stage of lactation. Each animal was fed on a basal diet, comprising $50 \mathrm{~kg}$ green fodder, $2 \mathrm{~kg}$ wheat straw, $0.75 \mathrm{~kg}$ cotton seed and $8 \mathrm{~kg}$ concentrate mixture per day as per requirements and free access to drinking water.

After recording the baseline information daily for 3 weeks, animals were offered ad libitum control diet supplemented with $200 \mathrm{~g}$ bypass fat (calcium salts of rice bran oil fatty acids was procured from Animal Nutrition Department, GADVASU, Ludhiana) for 7 weeks, per animal per day.

\section{Sample collection and chemical analysis}

Feed intake of animals was measured weekly and samples of feed were collected for laboratory analysis. After being dried $\left(80^{\circ} \mathrm{C}\right)$ and ground to pass a $1 \mathrm{~mm}$ sieve, feed samples were analyzed in duplicate for dry matter content, total ash, nitrogen and ether extract (AOAC, 1995) and acid detergent fibre (ADF), acid detergent lignin (ADL), neutral detergent fibre (NDF) and cellulose (Robertson and Van Soest, 1981).

All cows were milked twice a day at 05:00 and 15:00 h. Milk yields were individually recorded daily. Samples of milk (approx. two liters) were drawn weekly from each animal and were analyzed for fat, solids-not-fat (SNF) and protein content by a MilkoScreen (Indifoss Analytical Pvt. Ltd., Ahmedabad, India). Cream was separated from the each of the individual milk samples by centrifugal method in the cream separator. Milk corrected for its fat and protein content to a standard of 
$4.0 \%$ fat and $3.3 \%$ protein. This is a standard used for comparing milk with different fat and protein contents. The yield of fat proteincorrected milk (FPCM) was also estimated.

Cream samples were then converted in to ghee by direct cream method as described by De (2005). The ghee samples were stored in refrigerator $\left(4^{\circ} \mathrm{C}\right)$ until for further analysis.

The ghee samples were analyzed for Reichert Meissl (RM) and Polenske value (PV) as per the standard procedure (IS, 1966).

Butyro refractometer (BR) reading and refractive index (RI) of ghee was measured using digital butyro refractometer (Atago Co Ltd, Tokyo, Japan).

\section{Statistical analysis}

Results were expressed as overall mean \pm sd values of different parameters before and after supplementation of bypass fat to crossbred cows. The data were analyzed by $t$-test using the procedures described by SPSS (1996). Significance was declared at $\mathrm{P}<0.05$.

\section{Results and Discussion}

The chemical and nutrient compositions of feeds used in the experiment are shown in Table 1 . The dry matter intake of animals was $17 \mathrm{~kg}$ /day/animal and the roughage to concentrate ratio was observed to be 45.6 to 54.4 .

On supplementation of bypass fat in the diet of crossbred cows, average milk yield increased (p>0.05) from 18.66 to $20.50 \mathrm{~kg} / \mathrm{d}$ (Table 2), confirming the earlier report of increase in milk yield of crossbred cows in early lactation (Erickson et al., 1992; Garg et al., 2008; Naik et al., 2009; Wadhwa et al., 2012), however significant difference was not observed. The increase in milk production is mainly because of improved energy status of the animals especially in early lactation. However, other researchers reported no improvement in milk yields (Klusmeyer et al., 1991; Sklan et al., 1992; Elliott et al., 1996; Lounglawan et al., 2007) or milk fat contents (Atwal et al., 1990; Garcia-Bojalil et al., 1998) from feeding rumen-bypass fat.

The bypass fat supplementation decreased $(\mathrm{P}<0.05)$ the protein and SNF content in milk but no significant difference in milk fat content. Some researchers reported that when rumen bypass fat was supplemented to the diet of dairy cows the reduction of fat and crude protein contents (Erickson et al., 1992; Sklan et al., 1992; Rodriguez et al., 1997) while other researchers found the increase of milk fat content (Klusmeyer et al., 1991; Elliott et al., 1996).

A reduction in milk protein contents might be a result of reducing microbial protein production (Rodriguez et al., 1997) or dilution of milk protein as higher milk volume synthesized is not synchronized with uptake of amino acids by the mammary gland (DePeters and Cant, 1992). Further, dietary fat impairs amino acids transport to mammary gland and decreases milk protein synthesis by inducing insulin resistance (Palmquist and Moser, 1981).

The total fat, protein and SNF yields were not altered by bypass supplementation. Supplementation of bypass fat during early lactation, resulted in higher $(p>0.05)$ fat protein-corrected milk yield in comparison to control group, however, significant difference was not observed. Sklan et al., (1989) reported that fat corrected milk yield was increased with calcium salts of fatty acid supplementation despite non-significant changes in milk yield and fat contents. 
Table.1 Chemical composition of feed and fodder offered during trial period

\begin{tabular}{|l|c|}
\hline Parameter & Chemical composition (\% dry matter basis) \\
\hline CP & 20.27 \\
\hline EE & 3.36 \\
\hline NDF & 44.47 \\
\hline ADF & 27.09 \\
\hline ADL & 6.01 \\
\hline Cellulose & 20.67 \\
\hline Ash & 9.62 \\
\hline
\end{tabular}

Results are expressed as Mean values ( $\mathrm{n}=3$ ).

$\mathrm{CP}=$ crude protein $; \mathrm{EE}=$ ether extract; $\mathrm{NDF}=$ neutral detergent fibre $; \mathrm{ADF}=$ acid detergent fibre $\mathrm{ADL}=$ acid detergent lignin

Table.2 Effect of supplementation of bypass fat on milk yield and its Composition in crossbred cows

\begin{tabular}{|l|c|c|c|}
\hline Parameter & Control & Experimental & p-value \\
\hline Milk yield, kg/d & $18.66 \pm 2.809^{\mathrm{a}}$ & $20.50 \pm 2.37^{\mathrm{a}}$ & 0.068 \\
\hline Fat, \% & $2.98 \pm 1.153^{\mathrm{a}}$ & $3.24 \pm 0.503^{\mathrm{b}}$ & 0.021 \\
\hline Protein, \% & $3.35 \pm 0.177^{\mathrm{b}}$ & $2.90 \pm 0.294^{\mathrm{a}}$ & 0.003 \\
\hline SNF, \% & $9.52 \pm 0.286^{\mathrm{b}}$ & $8.85 \pm 0.376^{\mathrm{a}}$ & 0.00 \\
\hline Fat yield, kg/d & $0.56 \pm 0.241^{\mathrm{a}}$ & $0.66 \pm 0.126^{\mathrm{a}}$ & 0.073 \\
\hline Protein yield, kg/d & $0.62 \pm 0.097^{\mathrm{a}}$ & $0.60 \pm 0.077^{\mathrm{a}}$ & 0.412 \\
\hline SNF yield, kg/d & $1.78 \pm 0.134^{\mathrm{a}}$ & $1.82 \pm 0.145^{\mathrm{a}}$ & 0.690 \\
\hline FPCM yield, kg & $12.96 \pm 1.67^{\mathrm{a}}$ & $14.76 \pm 1.85^{\mathrm{a}}$ & 0.118 \\
\hline
\end{tabular}

Results are expressed as Mean \pm SD with different superscripts in each row differ significantly at $\mathrm{P}<0.05$; PSE, Pooled standard error; SNF - solids not fat; FPCM - fat protein corrected milk

Table.3 Effect of supplementation of bypass fat on chemical parameters of ghee

\begin{tabular}{|l|c|c|c|}
\hline Parameter & Control & Bypass fat & P-value \\
\hline RM value & $26.65 \pm 1.67^{\mathrm{a}}$ & $28.31 \pm 2.39^{\mathrm{a}}$ & 0.110 \\
\hline PV & $1.17 \pm 0.283^{\mathrm{b}}$ & $0.83 \pm 0.181^{\mathrm{a}}$ & 0.002 \\
\hline BR & $43.04 \pm 0.52^{\mathrm{a}}$ & $43.65 \pm 0.79^{\mathrm{a}}$ & 0.104 \\
\hline RI & $1.454 \pm 0.001^{\mathrm{a}}$ & $1.455 \pm 0.001^{\mathrm{a}}$ & 0.106 \\
\hline
\end{tabular}

Results are expressed as Mean $\pm \mathrm{SD}$ with different superscripts in each row differ significantly at $\mathrm{P}<0.05$ 
Table 3 represents the effect of bypass supplementation on chemical parameters of ghee in crossbred cows. On feeding bypass fat supplement to crossbred cows, RM value increased from 26.65 to 28.31 ( $\mathrm{P}>0.05)$. However, significant decrease $(\mathrm{P}<0.05)$ in $\mathrm{PV}$ was observed in experimental group. Beaulieu and Palmquist (1995) who observed an increase in proportion of $\mathrm{C}_{16: 0}$ to $\mathrm{C}_{18: 0}$ fatty acids and decrease in proportion of $\mathrm{C}_{8: 0}$ to $\mathrm{C}_{14: 0}$ fatty acids while butyric acid $\left(\mathrm{C}_{4: 0}\right)$ and caproic $\left(\mathrm{C}_{6: 0}\right)$ concentration were unaffected due to dietary fat supplementation in the form of calcium salts of palm oil fatty acids. Purushothaman et al., (2008) also found that supplemental dietary fat had no significant effect on concentration of butyric acid in milk fat. Supplementation of calcium salts of long chain fatty acids in the diet of lactating cows generally decreases the proportions of short and medium chain saturated fatty acids $\left(\mathrm{C}_{6: 0}\right.$ to $\left.\mathrm{C}_{16: 0}\right)$ of milk fat due to reduction in de novo fatty acid synthesis in mammary gland and increase in proportions of long chain fatty acids $\left(\mathrm{C}_{18: 1}, \mathrm{C}_{18: 2}, \mathrm{C}_{18: 3}\right)$ due to increased uptake of preformed long chain fatty acids from blood (Mishra et al., 2004).

The BR reading of the experimental and control group was 43.65 and 43.04, respectively. However, the dietary supplementation of bypass fat did not show any significant impact on RI and BR reading of ghee sample.

The study revealed that bypass fat supplementation to lactating crossbred cows is beneficial in terms of improvement in milk yield and FPCM yield but significant decrease in SNF and protein content in milk. Bypass supplementation significantly decrease PV of ghee, however, no such effect on RM value, BR reading and RI of ghee.

\section{Acknowledgement}

Authors are thankful to the Punjab State Cooperative Milk Producer's Federation Limited, Chandigarh for providing financial assistance for carrying out this research work.

\section{References}

AOAC. 1995. Official Methods of Analysis. 7 edn. Association of Official Analytical Chemists, Arlington, Virgina, USA.

Atwal, A.S., Hidiroglou, M., Kramer, J.K.G., and Binns, M.R. 1990. Effects of feeding $\alpha$-tocopherol and calcium salts of fatty acids on vitamin $\mathrm{E}$ and fatty acid composition of cow's milk. J. Dairy Sci. 73(10): 2832-2841.

Beaulieu, A.D., and Palmquist, D.L. 1995. Differential effects of high fat diets on fatty acid compositions in milk of Jersey and Holestein cows. J. Dairy Sci. 78(6): 1336-1344.

Cranfield, H.T. 1911. The effect of feeding cocoanut cake and linseed cake on the composition of butter-fat. Analyst 36: 445-449.

Cranfield, H.T., and Taylor, M.G.D. 1915. The effect of feeding on the composition of milk and butter: linseed cake and hempseed cake. Analyst 40: 433-439.

De, S. 2005. Outlines of Dairy Technology. Oxford Publishing Company, New Delhi.

DePeters, E.J. and Cant, J.P. 1992. Nutritional factors influencing the nitrogen composition of bovine milk: a review. J. Dairy Sci. 75(8): 2043-2070.

Elliott, J.P., Drackley, J.K., and Weigel, D.J. 1996. Digestability and effects of hydrogenated palm fatty acid distillate in lactating dairy cows. J. Dairy Sci. 79(6): 1031-1039.

Erickson, P.S., Murphy, M.R., and Clark, J.H. 1992. Supplementation of dairy cow diets with calcium salts of long-chain fatty acids and nicotinic acid in early lactation. J. Dairy Sci. 75(1): 1078-1089.

Garcia-Bojalil, C.M., Staples, C.R., Risco, C.A., Savio, J.D., and Thatcher, W.W. 1998. Protein degradability and calcium salts of long-chain fatty acids in the diets of lactating dairy cows: Productive responses. J. Dairy Sci. 81(5): 1374-1384.

Garg, M.R., Sherasia, P.L., Bhanderi, B.M., Gulati, S.K., and Scott, T.W. 2008. Effect of feeding bypass fat supplement on milk 
production and characteristics of butter fat. Indian J. Dairy Sci. 61(1): 56-61.

IS. 1966. Methods of sampling and test for ghee (butter fat) (3508: 1966). Bureau of Indian Standards, Manak Bhavan, New Delhi.

Klusmeyer, T.H., Lynch, G.L., Clark, J.H., and Nelson, D.R. 1991. Effects of calcium salts of fatty acids and proportion of forage in diet on ruminal fermentation and nutrient flow to the duodenum of cows. J. Dairy Sci. 74(7): 2220-2232.

Lounglawan, P., Suksombat, W., and Chullanandana, K. 2007. The effect of ruminal bypass fat on milk yields and milk composition of lactating dairy cow. Suranaree J. Sci. Technol. 14(1): 109117.

Mishra, S., Thakur, S.S., and Raikwar, R. 2004. Milk production and composition in crossbred cows fed calcium salts of mustard oil fatty acids. Indian J. An. Nutr. 21: 22-25.

Naik, P.K., Saijpaul, S., and Rani, N. 2009. Lactation response of crossbred dairy cows fed on indigenously prepared rumen protected fat - a field trial. Indian J. An. Sci. 79(10): 1045-1049.

Palmquist, D.L., and Moser, E.A. 1981. Dietary fat effects on blood insulin, glucose utilization and milk protein content of lactating cows. J. Dairy Sci. 64(8): 16641670.

Purushothaman, S., Kumar, A., and Tiwari, D.P. 2008. Effect of feeding calcium salts of palm oil fatty acids on performance of lactating crossbred cows. AsianAustralian J. An. Sci. 21(3): 376-385.

Robertson, J.A., and Van Soest, P.J. 1981. The detergent system of analysis and its application on human food. In: The
Analysis of Dietary Fibre in Food (Eds.) W.P.T. James and O. Theander. Marcel Dekkar Inc., New York, Pp.123-158.

Rodriguez, L.A., Stallings, C.C., Herbein, J.H., and McGilliard, M.L. 1997. Effect of degradability of dietary protein and fat on ruminal, blood, and milk components of Jersey and Holstein cows. J. Dairy Sci. 80(2): 353-363.

Sklan, D., Ashkenazi, R., Braun, A., Devorin, A., and Tabori, K. 1992. Fatty acids, calcium soaps of fatty acids, and cottonseeds fed to high yielding cows. J. Dairy Sci. 75(9): 2463-2472.

Sklan, D., Bogin, E., Avidar, Y., and Gur-Arie, S. 1989. Feeding calcium soaps of fatty acids to lactating cows: effect on production, body condition and blood lipids. J. Dairy Res. 56: 675-681.

Smith, F.H., Wells, C.A., and Ewing, P.V. 1916. The changes in composition of butter fat produced by feeding cottonseed oil. Bulletin (Georgia Experiment Station), Experiment, Ga.

SPSS. 1996. Statistical Packages for Social Sciences. Version 12.0, SPSS Inc., Linois, USA.

Tripathi, M.K. 2014. Effect of nutrition on production, composition, fatty acids and neutrceutical properties of milk. J. Adv. Dairy Res. 2(2): 115.

Tyagi, N., Thakur, S.S., and Shelke, S.K. 2009. Effect of feeding bypass fat supplement on milk yield, its composition and nutrient utilization in crossbred cows. Indian J. An. Nutr. 26(1): 1-8.

Wadhwa, M., Grewal, R.S., Bakshi, M.P.S., and Brar, P.S. 2012. Effect of supplementing bypass fat on the performance of high yielding crossbred cows. Indian J. An. Sci. 82(2): 200-203.

\section{How to cite this article:}

Veena, N., M. Wadhwa, H. Mehta, A.K. Barui, A.K. Puniya, J.S. Hundal and Grewal, R.S. 2018. Effect of Supplementing Bypass Fat on Milk Yield, Milk Composition and Chemical Parameters of Ghee in Crossbred Cows. Int.J.Curr.Microbiol.App.Sci. 7(10): 2604-2609. doi: https://doi.org/10.20546/ijcmas.2018.710.302 